\title{
ARTICLE
}

\section{Maurice Merleau-Ponty on Violence and Marxism}

\author{
Mihnea Chiujdea*
}

This article aims to examine the main tenets of Merleau-Ponty's political thought. To this end, his early Marxism and his later support for Liberalism are contextualised within Merleau-Ponty's philosophical work, put into relation and both criticised. The focus of the discussion is shifted onto the role and locus of the political thinker in order to evaluate the scope of a political project such as Marxism might have. It is divided into three sections. The first explores the themes of the philosophy developed until the early 1950s. The two sections that follow aim to critique his later work and to integrate and relate its arguments to earlier writings.

The objective of this article is to offer a reassessment of Merleau-Ponty's early and late political thought, looking at the role and place of the political thinker. Given that the philosopher is always 'situated' in a particular context, in attempting to provide an exegesis of the political philosophy of Maurice Merleau-Ponty, the focus of this paper will be on the shortcomings resulting from a sociopolitical materialist critique that fails to take the situatedness of its author into account.

Merleau-Ponty's conceptualisations of violence and intersubjectivity are central to his political philosophy until the early 1950s: they form the basis of his critique of liberalism and his espousal of Marxism. With this in mind, I argue that an evaluation of his later ideas reveals a certain lack of rigour and dishonesty. Indeed, an analysis that confronts his later work on politics with his earlier thought serves to expose the subjective locus of the philosopher in wider society and the limits of a pattern-based theory of change.

\footnotetext{
* University College London, United Kingdom m.chiujdea@ucl.ac.uk
}

\section{The early writings: the critique of liberalism and the implications of Marxism}

\section{Politics and Violence}

For Merleau-Ponty, the defining characteristic of man's being-in-the-world is the ability to transform nature through the creation of social structures or institutions. This is not simply a case of adapting nature to economic necessity or creating a second nature, but a matter of transcending biological nature in order to form society. Man is in a dialectical relation with the social structure. The lattera human creation in itself - shapes our mentalities and the way we perceive the world. Over time, however, social structures sediment; they become abstract and rigid; they no longer correspond to the way life is lived in a given society or period. Yet precisely in this lies human liberty: the ability to transcend these socially constructed structures (Kruks 1981: 37-56) - the freedom for political action. As this transcendence of social structures comes about as the result of the sum of individual projects, it follows that praxis is the result of intersubjectivity. In other words, political action is the result of the coming 
together of individuals who, because they have a similar - though not necessarily identical - perception of their condition, identify with common projects, join and act upon them in chorus. As Merleau-Ponty argues: 'We therefore recognise, around our initiatives and around that strictly individual project which is oneself, a zone of generalised existence and of projects already formed, significances which trail between ourselves and things and which confer upon us the quality of man' (1992: 450).

In turn, by attaching meaning to common projects, intersubjectivity gives human history direction and meaning. It also creates room for 'humanism' - which Merleau-Ponty defines as men relating to other men as men, and not objectifying them as the Other.

The interpretation that Merleau-Ponty gives of the political trials of the 1930s held under Stalin's rule in the Soviet Union follows from this phenomenological understanding of political action. In Humanism and Terror (1969) he contests the psychological, subjectivistic and solipsistic explanation of these trials given by Arthur Koestler in Darkness at Noon (2005). In contrast, Merleau-Ponty attributes Nikolai Bukharin's admitted guilt of treason to the contingent nature of history:

[His] collaboration is thereby transformed into voluntary betrayal. There is a sort of maleficence in history: it solicits men, tempts them so that they believe they are moving in its direction, and then suddenly it unmasks, and events change and prove that there was another possibility. [...] And they are unable to look for excuses or to excuse themselves from even a part of the responsibility. (1969: 40)

This understanding of Bukharin's drama underscores the possibility of misreading the meaning of the common projects that constitute the basis of human action. It shows that history is not scientifically predictable. Furthermore, this reading gives value to an objective judgement of political acts, attributing responsibility to the individual actors and to them alone. In politics, actions are judged according to their consequences rather than according to abstract values. This is why, in Merleau-Ponty's view, Bukharin has confessed his guilt of treason although he has denied other accusations that he deemed false. Even if, from a subjective point of view, his acts were not intended to betray Socialism as such, the movement of history gave them this meaning. This is not to be understood as a moral apology for opportunism - a stance that Merleau-Ponty criticises in the Introduction to Humanism and Terror. Rather, it illustrates that righteous morals or good intentions are not sufficient to guarantee positive outcomes, or, in other words, 'in historical action, goodness is sometimes catastrophic and cruelty less cruel than the easy-going mood' (Merleau-Ponty 1994: 126).

In his phenomenological studies, he speaks of a will to assign meaning to things in a struggle for self-assertion, which in itself is an act of violence. It is on this basis that he interprets the Hegelian master-slave (or subject-object) relation as a source of violence. He argues that,

Inasmuch as self-consciousness gives
meaning and value to every object
that we can grasp it is by nature in a
state of vertigo and it is a permanent
temptation for it to assert itself at the
expense of the other consciousnesses
who dispute its privilege. [...] Thus
history is essentially a struggle - the
struggle of the master and the slave,
the struggle between classes - and
this is necessary of the human condi-
tion. (Merleau-Ponty 1969: 102)

The philosophical analysis of subject and object is beyond the scope of this paper. Yet it is worth noting that Merleau-Ponty follows Marx in identifying class struggle with the Hegelian-type relation: one class thinks of another as object (the Other) and this is the 
reason why 'struggle' and master-slave relations exist. Merleau-Ponty offers an overview of the violence propagated by capitalism, ranging from colonialism to the wage system and unemployment (1969: 103). Besides these examples of the capitalist institutionalisation of violence (Crossley 1994: 52-54), Merleau-Ponty's criticism of liberal capitalism stresses that it imposes its abstract values on people dogmatically, concluding that '[an] aggressive liberalism exists which is a dogma and already an ideology of war' (1969: xxiv). It then claims the universality of these same values and thereby denies space for reflection. Consequently, capitalism prevents progress towards the disappearance of classes, and therefore intersubjectivity.

\section{Kantian liberalism}

When discussing liberalism Merleau-Ponty generally refers to Kantian liberalism. In his opinion, this replaces political thought with deontological ethics. In so far as it condones and masks violence, this kind of liberalism is regressive and renders intersubjective relations impossible.

As suggested above, by creating a class system, one of the sources of violence in capitalism is the way classes bring the subjectobject and master-slave type relations to the wider society. The proletariat is for instance objectified and exploited by the bourgeoisie by being transformed into nothing more than a means of making profit. What is more, Merleau-Ponty also tells us:

[T]he liberty-idol on a flag or in a constitution [...] legitimates the classical means of police and military oppression [...]. We must remember that liberty becomes a false ensign - a "solemn complement" of violence - as soon as it becomes only an idea and we begin to defend liberty instead of free men. [...] It is the essence of liberty to exist only in the practice of liberty. [...] In isolation, or understood as a principle of discrimination, [...] liberty is nothing more than a cruel god demanding his hecatombs. (1969: xxiv)

A few points deriving from this passage deserve clarification. Firstly, liberalism seems to fail to account for any concrete political experience, replacing this with ideology. It does not comprehend violence phenomenologically, as a lived experience of embodied political beings. Instead of aiming to extend the field of concrete liberty offered by society, it focuses on abstract notions and institutions that only in principle are supposed to ensure freedom. Liberalism replaces factuality with values and ethics, and in doing so it claims to have eradicated violence when it merely fails to understand it accurately. It is therefore a dishonest and regressive ideology.

Secondly, the issue of isolation is also raised. Sonia Kruks points out how MerleauPonty identifies liberalism with the Kantian categorical imperative and deontological ethics (1987: 160-183). For Kant, men, as embodied political actors, are reduced to pure 'consciousnesses' in the Cartesian sense. Consequently, by considering men fully rational, liberalism seems to claim that violence in all its forms is something of an isolated event that should not, and normally does not, happen. In turn, this conceptual framework serves to mask violence and to embed it in the political realm. It is for this reason that liberalism precludes the possibility of overcoming violence. In fact, liberalism institutionalises violence.

In the introduction to Humanism and Terror, Merleau-Ponty discusses the deontological ethics of liberalism. There, he argues that such an ethical system is simply not realistic. In politics, always restraining from violence - even towards a person or a class that is doing violence to another entity - is in itself an act of violence. Indeed, not using violence in order to stop another violent act is a tacit form condoning that act. The main point here, which is elaborated on in Merleau-Ponty's autobiographically-inspired discussion of the experience of war (Kruks 
1981: 139-152), is that the idealist nature of the ethical imperative of liberalism blurs the importance of choice in politics. The political nature of our being-in-the-world very often compels us to choose between alternatives that are laid before us and which force us to do violence. Thus, Merleau-Ponty argues, morally correct actions should aim at limiting violence and treating fellow men as men and not objects, rather than following any sort of categorical imperative.

Finally, Kruks also argues that by reducing men to inward consciousnesses, liberalism makes intersubjectivity impossible (1981: 160-176). For Merleau-Ponty, it is through intersubjectivity that truth and meaning come into being. The possibility to interact with others and confront one's perceptions of reality is the only means of telling the difference between truth and hallucination. As such, the (liberal) cogito renders truth - which has a public nature and thus only happens within society - impossible. Furthermore, without intersubjectivity, action loses its meaning, collective projects become impossible and history turns into nothing but an amalgam of random and absurd events. Hence, it must be emphasised that through its solipsistic conceptualisation of society, liberal capitalism is not only detrimental for the exploited, for the victims of violence (e.g. the proletariat, the colonised) but it is harmful for the whole of society.

\section{Objections to Merleau-Ponty's critique of liberalism}

Barry Cooper criticises Merleau-Ponty's argument about the undeniable presence of violence in politics, and the need to acknowledge it and act accordingly. Cooper argues:

Here, then, one must question Merleau-Ponty's charge that all non-violence was 'Quaker hypocrisy'. [...] [T] he genuinely non-violent person does not simply wish for a non-violent world, he commits himself to it, even to the point of suffering rather than inflicting violence. [...] The choice of the political person who may have to rely on violence can be met on equal terms by the non-violent person whose refusal of violence is an affirmation of truths beyond history. (1979: 47)

In my view, this objection does not seem to be convincing because it appears to consist of a reformulation of Kantian ethics that does little in the way of engaging with Merleau-Ponty's argument. For Cooper it seems that choosing to be non-violent can only result in sufferings for the non-violent person (who sacrifices him/herself); what he appears not to appreciate is that the effects of human action (even if they are guided by the will to avoid violence at any price) are not only suffered by the acting subject. In the essay The War Has Taken Place MerleauPonty shows how in extreme situations (and not only) men are faced with a strict set of choices which they are forced to make. Situations assign roles onto political actors altering the meaning of decisions and behaviours (Merleau-Ponty 1964: 144). In other words, even if, as Cooper suggests, one pretends that one does not have to choose between a set of given violent actions, what one does can still have a violent and regressive character. Just as much as it was a sham for an Allied soldier in World War Two to claim that for the sake of peace he would not commit an act of violence against a Nazi soldier guarding Auschwitz, it similarly is fallacious for Cooper to deny the necessity of violence in the realm of politics.

A more justified objection to MerleauPonty's discussion of violence has been raised $^{2}$, namely, that he fails to define the concept and distinguish between different types of violence. It is perhaps for this reason that the only qualitative distinction between types of violence for him is between regressive and progressive (i.e. violence that perpetuates itself or that which aims at its own suppression). This argument is weak to the extent that it can be manipulated to justify almost any kind of violence as com- 
munist regimes in the past and present demonstrate. For Merleau-Ponty the dialectic of history is never closed. Given that violence is something that will never be eradicated completely from politics, this qualitative differentiation becomes quantitative. In other words, the only justification for (progressive) violence is a balance sheet between the present and a better future. Not only is this kind of assessment not possible because the future is never certain but one cannot justify violence happening in the present, and against people living in it, for the betterment of unborn generations. There is simply no common denominator between the present and the future that would make justice to this conceptualisation.

Finally, Kruks argues that Merleau-Ponty's critique of liberalism is not rigorous enough in so far as it merely consists of a critique of Kant, Descartes and Alain. She further notes how Anglo-Saxon liberal thought has developed by acknowledging the violence in politics and with the aim of managing it through the social covenant (Kruks 1987: 183-192). One could argue that Merleau-Ponty would have considered liberalism, at the time when it arose, a progressive ideology with at least some benefits. However, as Kruks points out herself, liberalism for him, at the point when he was writing, was identical with Alain-ism (and the Kantian and Cartesian influences that his thoughts reflected). Indeed, at that time, the ideas of Alain-ism dominated liberal thought. What Merleau-Ponty criticises is the equation of liberalism with Alain-ism in France. His thinking about ideologies can thus be described as a process approach: as with social structures, these are not defined, for him, by the values they promote (not by the pattern they aim to see society reflect) but by the way they mutate and by what they mean to a certain society at a certain time. In other words, ideologies are to be judged according to the quality they give to political violence - be it progressive or regressive. Thus it is not so much lack of rigour on Merleau-Ponty's behalf that led him to ignore the writings of political thinkers such as
John Locke (and for instance in this respect, the importance of 'bodily passions', see Locke 1960). Rather, it was his way of showing what liberalism had in his view become: nothing more than a rigid institution bearing the sediment of history and restricting human freedom.

\section{Marxism. The Truth of History}

Lefort points out how Merleau-Ponty does not make Marx an object of his study. He takes certain concepts for granted without discussing them openly and explicitly (e.g. history). He assumes that his reader will be acquainted with the works of Marx and will have had an opportunity to experience these issues first-hand (Lefort 1978: 75). $\mathrm{He}$ also does not find it worth distinguishing between Marx's Marxism and the ideas which have been developed by other Marxists, faithful or not, such as Lenin. In other words, he considers Marxism (like capitalism) to be a 'living' ideology, a body of thought that develops and mutates according to history and according to its scholars.

When speaking of the (ideal) communist Merleau-Ponty claims that ' $\mathrm{h}$ ]e has to learn to recognise the play of opposing forces, and those writers, even the reactionary ones who have described it are more precious for communism than those, however progressive, who have masked it with liberal illusions. Machiavelli is worth more than Kant' (1969: 104). The Machiavellian nature of communism is a recurrent theme throughout his early writings. Apart from an honest recognition of the realpolitik nature of government, it is also superior to liberalism in that it can justify its revolutionary violence as being progressive and thus possibly making humanism possible in the future (MerleauPonty 1969: 107).

This conception of praxis resembles Kant's categorical imperative, namely: 'Act in such a way that you treat humanity, whether in your own person or in the person of any other, never merely as a means to an end, but always at the same time as an end' (Kant 1993: 36). The main difference between the two con- 
ceptions is that Merleau-Ponty acknowledges the presence of violence in society at present, thus contradicting the point made by Kant in his essay 'Theory and Practice' (in Kant and Reiss 1991: 61-92). What for Kant was a principle of guiding all ethical action, for Merleau-Ponty is a desirable state that society can reach in the future. Conversely, certain types of violence are desirable in the present inasmuch as they bring the possibility of the applicability of the Kantian Imperative in the future. The reason why violence is indispensable is that even after bourgeois liberalism is replaced by socialism, the governing machineries remain an inheritance of capitalism, and, as a result, still need violence in order to function (Merleau-Ponty 1969: 103-107). This is why, following Trotsky, Merleau-Ponty concludes that violence under communism is like a lamp that produces maximum light before going out (1969: 86).

Acknowledging the presence of violence in society enables Merleau-Ponty to come up with a second and more sophisticated justification for revolutionary violence: '[T] he proletarians "who are not gods" are the only ones in a position to realise humanity' (1969: 11), he claims. The reason for assigning this role to the proletariat lies in the dialectic between the objective and the subjective nature of the proletariat as the universal class. Merleau-Ponty is a materialist in his early writings so he holds that the workers are themselves the 'result' of exploitation and of universal dependency as alienation. This makes for the objective aspect of the revolution. Their praxis aims at doing away with the conditions that created them as the exploited class and precludes intersubjectivity. However, as opposed to the Hegelian 'class' of bureaucrats, the workers are not 'guarding' or trying to implement a pattern made up of a set of purely intellectual, arbitrary, supreme or objective values. Revolutionary praxis is a result of the subjective and individual experiences of capitalism that makes each worker want to engage in a common project. This consciousness of their condition results in the spontaneity of the Revo- lution. These two characteristics cannot be separated: the workers develop a consciousness of their condition because they experience the effects of capitalism most strongly. Marxist praxis results from the perfect dialectic between the two extremes. This is why Merleau-Ponty argues that, '[f]or the proletarian individuality or self-consciousness and class-consciousness are absolutely identical' (1969: 115).

However, since the proletariat does not always attain self-consciousness by itself, there is sometimes the need for party intervention. Merleau-Ponty does not take on board the early Marxist idea according to which the party's role is to be in continual contact with the proletariat, drawing from it directly the meaning of its decisions and actions. Instead Merleau-Ponty repeatedly quotes Lenin saying:

Lenin thought that the Party should not be behind the proletariat, nor besides it, but rather ahead of it, though only one step ahead. [...] The Party leads the existing proletariat in the name of an idea of the proletariat which it draws from its philosophy of history and which does not coincide at every moment with the will and sentiment of the proletariat person. (1969: 85)

Yet, following Lenin again he states that, 'under pain of losing its meaning compromise can only be practiced "in order to raise - not lower - the general level of proletarian class-consciousness"' (Merleau-Ponty 1969: 118). It is surprising how little heed MerleauPonty pays to the role of elites and personnel in the state bureaucracy. Moreover, the passage above shows again how the qualitative differentiation between types of violence slips into a quantitative one: whether a political thinker can define 'only one step ahead' without indirectly legitimising virtually any sort of propaganda and totalitarian state intervention is perhaps an unanswerable question. 
Considering that Revolutionary action is defined by the dialectic between the objective and subjective, the objective aspect this is reflect in his discussion of the theme of history. Indeed, the phrase 'sense of history' is a leitmotif in all of Merleau-Ponty's political writings. The Collins French Dictionary defines 'sens' as both meaning and direction (The Collins French Dictionary n.d.). For Merleau-Ponty, then, history acquires direction through the way events acquire meaning; these are not isolated events created out of nothingness as they are for Sartre. I have already touched upon the fact that, on the one hand, man is in a dialectical relationship with social structures and that, on the other, truth has a public character. Through a shared perception of the world, collective political action becomes possible and history gains meaning in a manner that makes it, to a degree, predictable. In other words, the direction of history stems from the will to freedom, to transcend sedimented institutions through collective projects. But Merleau-Ponty is always careful to stress that history, although it has sense, is contingent:

If it is true that the state as we know it is the instrument of a class, we may assume that it "will wither away" with the disappearance of classes. But Lenin carefully points out that "it has never entered the head of any socialist "to promise" that the higher phase of development of Communism will arrive." (1969: 105)

There is then an apparent tension between the sense of history and the fact that there is no acceptable reason why we should believe that communism in its fullness will ever become reality. However, I do not believe that this constitutes a contradiction in MerleauPonty's thought as such. Rather, it is a case of rejection of the later Marx, who, in his scientific socialism, contended that communism is gestant in capitalism's modes of exploitation and means of production. Merleau-Ponty would simply argue that it is likely for capi- talism to be overthrown; it is likely that the masses will eventually understand their own condition and unite in a common project. Yet another event could always re-shape the constellation of meanings and history could take a more unpredictable turn. Conversely, the fact that the meaning of praxis and the sense of history can only be fully understood $a$ posteriori raises questions about the role of the party in making this pre-conceived meaning clear to the proletariat.

Merleau-Ponty never joined the French Communist Party (Coole 2007: 3-9). Besides his disillusionment with the party as such, it would appear that his detached, critical support for Marxism resulted from this perceived conflict between the claim that history has meaning, which we can grasp, and the view that history is contingent (Merleau-Ponty 1964). On the one hand, he argues that,

On close consideration, Marxism is not just any hypothesis that might be replaced tomorrow by some other. It is the simple statement of those conditions without which there would be neither any humanism, in the sense of a mutual relation between men, nor any rationality in history. In this sense Marxism is not a philosophy of history; it is the philosophy of history and to denounce it is to dig the grave of Reason in history. After that there can be no more dreams or adventures. (Merleau-Ponty 1969: 153)

In other words, to deny Marxism's meaning even as a critique of the current situation under bourgeois rule would not only mean, for Merleau-Ponty, the impossibility of limiting violence and class exploitation; it would also mean that intersubjectivity and common projects are impossible and that man has no powers over social structures (i.e. his freedom is never anything more than the freedom to will freedom but never to experience it fully). It would mean that men are reduced to Carthesian rational consciousnesses and that society is nothing but a second nature. 
Finally, it would have consequences not only for his political arguments but for his entire phenomenology.

On the other hand, Merleau-Ponty remains critical of Marxism, referring to the possibility that the USSR may become just another regressive regime:

One cannot postpone indefinitely the need to decide whether or not history has received the proletarian philosophy of history. [...] But although two, three or four grains of sand do not make a heap, after a while the heap is there and that nobody can doubt. (1969: 153)

In accordance with his phenomenological understanding of politics, only experience will be able to prove (or disprove) the validity of Marxism. At the time when Humanism and Terror was written the USSR was at a crossroads between acknowledging the need to make compromises in order to fulfil the historical mission of Marxism and just professing unbounded violence. The subsequent flow of events alone would tell whether Marxism deserved being denounced. However, here too Merleau-Ponty resorts to a qualitative analysis of violence that is never conceptualised clearly. Moreover, it is doubtful whether the Soviet experience can be taken as testimony on the value of the Marxist ideology considering that Russia never attained the necessary industrial development required by the conversion to Communism, as prescribed by this ideology. These shortfalls perhaps resulted from MerleauPonty's tendency to phenomenologise politics: his desire to judge an ideology according to the concrete experience of living under a system that reflects its claims. However, judging Marxism as a whole (be it the writings of Marx himself or of the body of thought called Marxism that resulted) according to its main 'embodiment' at that time (i.e. Soviet governments) was perhaps not the most astute idea as it cannot be guaranteed that the latter is an honest realisation of the former.
Crossley criticises Merleau-Ponty's Marxism for analysing the social struggle and violence from the standpoint of economic relations only (1994: 55-61). Indeed, Merleau-Ponty claims that Marxism is an all-inclusive method of social critique. He believes that it contextualises apparently isolated events and relates them to the social whole by giving them meaning. He goes so far as to state that Marxism is a philosophy of mind that only illustrates its tenets with reference to economics (Merleau-Ponty 1964). While in Humanism and Terror he declares his Marxist critique has a broad focus, analysing all at once 'forms of labour, ways of loving, living and dying' (Merleau-Ponty 1969: 60), he ends up only ever referring to the political apparatus that sustains these 'forms of labour'. Neither does he offer a philosophical, nor an empirical explanation for his belief that all social relations are revealed by economics. As Crossley points out, other perspectives such as gender can be just as informative and fruitful for the understanding and analysis of social formations.

However, it would appear that in his critique of liberalism and in his Marxism Merleau-Ponty sets the 'standards' for political thought. For him, what defines a political ideology is not merely what it stands for (its values), but the way it deals with violence and whether this is acknowledged, justified and progressive. This is why in his early writings he denounces liberalism as institutionalising regressive violence. What is more, intersubjectivity is what would enable men to join in common projects and make humanism possible. For Merleau-Ponty, making intersubjectivity possible is not so much a desideration of his political philosophy as it is a logical conclusion that derives from his phenomenological thought. In other words, if the members of the proletariat do not (and cannot) come together in a common project such as the Revolution, relating to one another intersubjectively, then it must be that we do not perceive reality and gain truth (by approximating another's perception of the world) as Merleau-Ponty has argued in 
his phenomenological studies. If intersubjectivity is not possible it could only mean that his phenomenological and epistemological thought needs revising.

\section{Later political writings: giving up Marxism}

Drawing on Simone de Beauvoir, Diana Coole suggests that Merleau-Ponty was influenced by the geopolitics of the 1950s in his denunciation of Marxism (2007: 3-9). Indeed, the USSR's role in the Korean War as well as the discovery of Soviet labour camps convince him to radically reconsider the arguments outlined in his earlier political works (Merleau-Ponty 1955: 129 and 1994: 216). By the mid-1950s, he breaks with Sartre and quits Les Temps Modernes ${ }^{1}$. After this, his only work entirely devoted to politics was the 1955 Adventures of the Dialectic. In what follows I will aim to argue that however valid his objections may have been, his overall critique comes across as clumsy, incoherent and somewhat dishonest. In denouncing Marxism he fails to meet the standards that he set in his earlier work. Moreover, he fails to address one of the fundamental questions for any political thinker: namely the position of the political philosopher in the dialectic between the objective and the subjective the issue of self-reflexivity.

The Adventures of the Dialectic seems to lack the pursuit of a core argument. In order to repudiate Soviet terror, the work expresses a drive to renounce Marxism at all costs. It consists of a series of essays, each of them offering an independent critique, which Merleau-Ponty then tries to piece together in his epilogue. In the introduction he praises Max Weber for his analysis of the relation between capitalism and Protestantism. In Weber's account he finds a new dialectical method according to which the strata constitutive of different cultural configurations (the political, the religious, the economic, and the legal) are understood to be in continuous interaction with one another. However, a change in one of these strata does not mean that the others will be affected. Their devel- opment is asynchronic. To use his example, though Protestantism may have facilitated the coming of capitalism, Merleau-Ponty argues it would be unjustified to claim that capitalism was a necessary consequence of Protestantism. In so doing, he distances himself from Marx, who Merleau-Ponty depicts as having affirmed that capitalism itself announces the dawns of communism. From this new perspective, there is absolutely no way of interpreting or understanding the course of history ahead of events taking place. Merleau-Ponty announces he wishes to apply this Weberian method in his analysis of the 'adventures' of Marxism but with regard to the text as a whole, this aim is then abandoned. Finally, while he states his admiration for a new type of liberalism, he never actually explains what it consists of and how it can help bring about the concrete liberties that he speaks about in his earlier works.

In proving that Marxism and the materialist dialectic are doomed to end up as a positivist, vulgar dialectic, Merleau-Ponty firstly considers the writings of Georg Lukacs, which had influenced him earlier. He begins by pointing out how the latter had started off with an open materialist dialectic in which communism was not an issue of necessity. At this stage, Merleau-Ponty still seems to endorse Lukacs's arguments. To some extent, it is hard to tell whether his reference to Lukacs was just a pretext for him to present his own conceptualisation of the dialectic or whether he is giving a genuine account of the latter's ideas. Merleau-Ponty then shows how, after having been criticised by the communist elites for his work, Lukacs reconsidered his position and adopted a position in line with the materialist positivistic dialectic. For Merleau-Ponty, this is proof that a materialist dialectic always ends up as a concrete dialectic. He concludes that there is something in the essence of Marxism, which leads to such malformations. However, this argument lacks any foundation and as Kruks has ventured, it was more likely a case of opportunism on Lukacs' behalf - an attempt to secure his ascension on the Hungarian political ladder 
by altering his philosophical stance - rather than something in the essence of Marxism that led him to change his mind (Kruks 1981: 266-270).

A similar line of argument is offered throughout the book. The open dialectic of the early Marx is criticised for turning into the positivism of his later writings and eventually leading to Soviet scientific socialism, the ideology of war and Soviet imperialism. Similarly, Merleau-Ponty tries to link Marxism to Sartre's view of Communism. There, intersubjectivity does not feature but is replaced by the proletariat's destructive gaze directed at the Other -namely the bourgeoisie. However, there is a huge leap between Marx's writings and affirming that 'Hell is other people' (Sartre 1989: 45).

Merleau-Ponty seems to want to offer a genealogy of Marxism and showing how Marxism developed and evolved. Yet, making Marx's Marxism (or perhaps the Marxism that Merleau-Ponty himself advocates in his early work) responsible for its subsequent unfortunate modifications would require a causal explanation: one that shows what transforms the open dialectic into Soviet Imperialism and Stalinist purges. And this he fails to do. One of Nietzsche's most valuable points in his genealogical studies is his overarching argument that the starting point of a set of values can end up entirely alienated from the future forms that it consequently takes (and that these future developments very often are not to be found in or announced by the initial form; Nietzsche 2007). In other words, even if it went astray and was bastardised by Lenin, transformed to accommodate such Sartrian concepts such as the Other, the objectifying gaze, and nothingness, it does not mean that the original Marxism (or any other type of Marxism) has anything to do with these later developments, nor does it mean that a new attempt at applying Marxism would produce similar results. Moreover, by claiming that because Marxism happened to be re-interpreted in toxic ways, it will necessarily always have these nefast consequences wherever implemented, is simply another form of positivism, this time on Merleau-Ponty's behalf.

His other main argument against Marxism concerns the role of the party and the elites. He argues that Soviet bureaucrats suffered from what he calls 'Bolshevist vertigo' (Merleau-Ponty 1955: 129). On this, Kruks comments as follows: 'In effect, MerleauPonty produces a variation of the old adage that 'power corrupts': power and a belief that one has the truth makes men frenzied. Such an adage, even if it was to contain a grain of truth, can hardly provide the grounds for rejecting Marxism' (1981: 287). It is probable, though, that Merleau-Ponty was making a more profound point here: once a certain limited group/class is granted the duty to clarify the meaning of history to the masses, these elites are already separated from the masses. As such, political action loses its spontaneity and the dialectic between the objective and subjective character of the proletariat is irremediably broken. The result can only be Hegel's idea of the 'state servants', or Plato's 'philosopher kings'. It is for this reason that he argues in the Epilogue of Adventures of the Dialectic that a revolutionary movement loses its revolutionary momentum once it becomes institutionalised and transformed into a regime. On the other hand, it is worth underlining that it is the Leninist conception of the party (i.e. 'one step ahead' of the proletariat) that Merleau-Ponty is criticising here so his analysis is not necessarily pertinent for Marx's Marxism.

\section{Broken promises? The philosophical condition}

Merleau-Ponty's political preference for Marxism is now replaced by a retreat into liberalism. Allegedly, this is a new type of liberalism, one that can make freedom possible - a superliberalism. However, the workings of this liberalism are not explained. The only thing Merleau-Ponty mentions is the importance of parliaments: 'Parliament is the only known institution that guarantees a minimum of opposition and of truth. There are other limitations which are the result of parliamentary 
usage and manoeuvres: these deserve no respect at all, but they can be denounced by Parliament itself' (Merleau-Ponty 1955: 226). The institution of parliament is quite a minimalist guarantee for effective political opposition and truth. There are countless examples of authoritarian regimes utterly suppressing opposition while maintaining parliamentary assemblies. Are not parliaments just another example of an institution that claims to safeguard negative rights (such as the right to political opposition) but that through its abstractness can only serve to mask violence? Does Merleau-Ponty's early criticism of liberal democracy not perfectly apply to this new form of liberalism that he now endorses? One could think of no reason why it would not and since he does not argue against his early criticism of abstract rights, his later apologetic stance with respect to this new liberalism is unconvincing.

What is more, arguing that Marxism is simply scientism, doomed to end up in this vulgar materialist positivism that serves to justify violence and tyranny, would mean (according to his early thought) that intersubjectivity is impossible. If the proletariat, who share similar living conditions, are not able to attain any self-consciousness and fail to identify in Marxism a 'common project', it means that his whole understanding of perception, and therefore his entire phenomenological project needs reviewing. Considering that this was the fundament for his epistemological studies, it would appear that truth, if we are ever able to attain it, does not happen in the way he described it. It would also mean that man is unable to attach meaning to common projects and that history is a 'sens'-less bundle of events.

Finally, the way in which Merleau-Ponty describes the condition and rights of the proletariat under this new kind of liberalism is again evidence of a certain degree of dishonesty in his argument. He claims:

There is a class struggle and there must be one, since there are, and as long as there will be classes. There is and there must be a means of exceptional action for the proletarian class, the strike, since its fate is also exceptional [...] Moreover, this party has the right to be represented [...] by a party which refuses the democratic game, since the game places it at a disadvantage. (Merleau-Ponty 1955: 225-226)

Whilst still accepting his early comments about the proletariat as the disadvantaged class (whose exploitation is facilitated by liberal democracy) he now only agrees to minor concessions such as preserving the right to strike and the right to be represented by the communist party. It is obvious that these do not pave the way for altering the condition of the proletariat and overcoming class struggle. By only minimally improving the life of the workers, this system merely conceals the struggle and institutionalises violence. It would also be paradoxical to find the existence of a communist party (which promotes a non-democratic political system) desirable if the overarching form of government is liberal parliamentarism. This only translates into a dishonest support for a new opium of the masses (the workers' advent of the Revolution), doubled by the belief that the Revolution or the coming to power of the communist party are indeed impossible.

Similarly, by acknowledging that the working class is the target of violence in bourgeois society, yet by condemning any Revolutionary violence (be that in the form of an actual revolution, or perhaps in milder forms, such as a tough taxation policy) Merleau-Ponty is tacitly agreeing with and promoting bourgeois violence. In a Kantian fashion, he is pretending that one has the possibility of not choosing violence when it is in fact a case of only being able to choose the type and the direction of the violence.

\section{The political philosopher and the dialectic} Lydia Goehr argues that for Merleau-Ponty, political thought is a form of political praxis (2005: 318-351). The thinker is engaged in politics simply by commenting and analys- 
ing politics. As mentioned in the previous section, Merleau-Ponty criticises the role Marxism attaches to political elites. But Lefort draws attention to a different issue: Merleau-Ponty never questions the role of the philosopher in the dialectic (1978: 45-104). It is clear that the philosopher who attempts to legitimise a certain kind of violence is himself a subjective voice. As such, he/she cannot claim that a class, namely the proletariat has an objective component (in what the objective-subjective-dialectic that defines the nature of proletarian action is concerned) once that claim is in itself subjective. As Merleau-Ponty notes a 'philosophy, like art and poetry belongs to a time' (1964: 132). The philosopher cannot use such a subjective claim to justify terror and the fate of the supra-structure, unless he/she becomes the Hegelian guardian or the Platonic philosopher king.

The question of the situated philosopher can be analysed by means of a materialist approach which claims that praxis is always embodied and that the embodied subject is always in direct relation with the world. In other words, the fact that our morals, beliefs and values, and indeed our whole worldview are influenced by the structure of the world we live in. If this is true, and if we live in a world where violence is regressive and where the political mechanism serves to justify and mask exploitation, there is no escape to our thinking reflecting this.

When disillusioned with Soviet Marxism it would appear that Merleau-Ponty had three options: he could have pressed on with his Marxist critique and with the occasional revisions, conceding that the Soviet Union was a malformation of Marxism. Indeed, it would have perhaps been difficult to come up with an explanation as to why this has happened and to publicly support an ideology that justified the Stalinist purges or the Korean War. His second option was quietism, a complete negation of his early writings: the claim that Marxism did not offer a viable alternative to the violence of liberalism and that even if regressive, this is still more desirable than Soviet terror. This option, which he seems to have chosen, would have also required a rejection and revision of his phenomenological thought, which his political work was so closely intertwined with. Finally, the third option was a re-examination of his own Marxist philosophy using a similar method as in his early critique of Liberalism.

In his early thought Merleau-Ponty would appear to have favoured a process-based as opposed to a pattern-based approach to change in society. He felt that it was almost irrelevant what values liberalism held dear. What mattered was mainly the violence that resulted from its institutions and class system. Conversely, Marxism was superior to the former, mainly because it could justify its violence, and because its violence was progressive. It would have perhaps been more profitable for Merleau-Ponty to keep this approach and to push this early materialism to its limits. In this way, he would have realised that Marxism's impotence to reshape the world of politics and social relations stemmed from the fact that its theorists were themselves subjective voices influenced by bourgeois capitalism.

This method can be illustrated by sketching an analysis of the role attributed to the communist party by Marxist thought. One can study this phenomenon of power-mongering without resorting to psychological concepts such as vertigo. Indeed, one could argue that it was because Marxist theory was developed under capitalism, where the bureaucracy's implicit role is to facilitate exploitation, that the new conceptualisation of the communist party led to its separation from the proletariat and the naissance of a new class. To take this argument further still, what Merleau-Ponty failed to see by radically dismissing materialism was that because we live in an essentially evil world of exploitation and because our way of thinking is inescapably influenced by social structures, one cannot justify every aspect of government using a preconceived pattern of what 
an ideal future would look like. This pattern in itself would be tainted by the supra-structure of the bourgeois world that we live in. Thus, the result of a project such as Marxism, envisaging change according to a minutely designed pattern of the desirable society can only be dystopian. Claiming otherwise would be Cartesian idealism, which is something that Merleau-Ponty rejected right until his death.

Hannah Arendt argues that it is praxis rather than a 'craftsmanship' of social structures that defines human interaction: institutions are the secondary results of human action (1998: 220-228). If this relation is conceived of in an inverted way, in order to resolve the problem of what Arendt calls the 'frailty of action' (the fact that action is not predictable, its effects spill over the initial meaning its authors intended and its final meaning can only be read once it is complete), if the fabrication of structures (as the result of philosophical thought) gains precedence over the engagement with others 'in word and deed', then society becomes an instrument directed against the individual. Often, this is achieved in accordance with the objective and pre-produced social structures conceived by the philosopher. As such, ever since Plato, the attempt to secure action, to make it predictable and malleable to the intentions of those who think they own an objective understanding of what the course of history will be, translates into terror. Similarly, it is precisely the fact that MerleauPonty fails to situate his philosopher ego in this materialist dialectic that limits the scope of his later critique of Marxism. For this reason his denunciation of Marxism has serious shortcomings: it comes short of living up to the expectations raised by his early work and fails to deliver on the promises that he made as a Marxist.

\section{Conclusion}

Closely influenced and intertwined with his phenomenological studies, Merleau-Ponty's political philosophy starts off by trying to move away from the Cartesian tendency of seeing individuals as multiple consciousnesses relating to one another as subjects and objects. Instead, it regards individuals as embodied entities which are in a dialectical relationship with the social structure. This conception enabled him to criticise liberalism for its institutionalisation of violence and to support Marxism reluctantly accepting its violent as long as this was progressive and honest. However, the turn of events in global politics convinced Merleau-Ponty to give up Marxism in order to support a new type of liberalism which is never fully conceptualised. Disappointingly, this accompanied by a quietist stance towards the general 'standards' the he previously set for himself in his earlier thought and is not followed by a re-evaluation of other areas of his philosophical work which were so closely related to his Marxism.

As the preceding discussion illustrates, the change in Merleau-Ponty's political thought was a result of what he felt was a more rigorous application of his focus on the tangible and experienced aspects of politics, rather than a shift in values and morals. I have argued that his later critique appears unconvincing as it lacks rigour and exhibits a sense of dishonesty, yet it thereby serves to illustrate a more general point about theories of change. Of course, it would be wrong to assume that theories of change or improvement can be either fully process- or patternbased. All such theories embody both of these approaches: if one were to claim with the early Merleau-Ponty that change should happen so that all violence is progressive (i.e. the purpose of change in society is to reduce violence) and in such way that intersubjectivity becomes possible, one would still conceptualise the process of change with a desirable pattern of society in mind. Indeed, a truly reflexive materialist approach, 'situating' the philosopher and defining him/her as a subjective voice, could be paralysing: it would follow that nothing can be said which is not polluted by the social structure. It would not 
appear however that Merleau-Ponty considered this particular argument to justify his renunciation of Marxism.

The solution may lie in modesty, in the admission of the limits that a political-philosophical project can and needs to have before it becomes the source of dystopias; in the reduction of ideologies to minimum 'standards' that change should aim to bring about; in the voicing of a critique of the status-quo. Yet, this should probably be paired with an acceptance that such standards are far from perfect, scarcely objective and that whilst they can serve to promote positive change in the present they might not do so in the long-term.

\section{Notes}

${ }^{1}$ Les Temps Modernes was a Cultural Review established in 1945 by MerleauPonty, Sartre and de Beauvoir.

${ }^{2}$ See for example: S. Kruks, The Political Philosophy of Merleau-Ponty (Sussex: Harvester Press 1981), pp. 76-82; B. Cooper, Merleau-Ponty and Marxism (Toronto: University of Toronto Press, 1979), pp. 37-40; N. Crossley, The Politics of Subjectivity, (Aldershot: Avebury, 1994), pp. 52-55.

\section{References}

Arendt, H 1998 The Human Condition. Chicago: University of Chicago Press.

Collins French Dictionary n.d. Available at http://www.collinslanguage.com/ [Last accessed 26 April 2011].

Coole D 2007 Merleau-Ponty and Modern Politics after Anti-Humanism. Lanham: Rowman \& Littlefield.

Cooper, B 1979 Merleau-Ponty and Marxism. London: University of Toronto Press.
Crossley, N 1994 The Politics of Subjectivity. Aldershot: Avebury.

Goehr, L 2005 Understanding the Engaged Philosopher. In: Hansen, M B N, et al (eds.) The Cambridge Companion to MerleauPonty. Cambridge: Cambridge University Press, pp. 318-351.

Kant, I 1785, 1993 ed. Grounding for the Metaphysics of Morals. Indianapolis: Hackett.

Kant, I, and Reiss, H S (ed.) 1991 Political Writings. Cambridge: Cambridge University Press.

Koestler, A 2005 Darkness at Noon. London: Vintage.

Kruks, S 1981 The Political Philosophy of Merleau-Ponty. Brighton: Harvester Press.

Kruks, S 1987 A Study of the Political Philosophy of Merleau-Ponty. London: Garland Publishing.

Lefort, C 1978 Sur une colonne absente. Paris: Gallimard.

Locke, J 1689, 1960 ed. Two Treatises of Government. Cambridge: Cambridge University Press.

Merleau-Ponty, M 1955 Adventures of the Dialectic. London: Heinemann.

Merleau-Ponty, M 1964 Sense and Nonsense. Evanston: Northwestern University Press.

Merleau-Ponty, M 1969 Humanism and Terror. Boston: Beacon Press.

Merleau-Ponty, M 1992 Phenomenology of Perception. London: Routledge.

Merleau-Ponty, M 1994 Signs. Evanston: Northwestern University Press.

Merleau-Ponty, M 1995 Adventures of the Dialectic. London: Heinemann.

Nietzsche, F 2007 On the Genealogy of Morality. New York: Cambridge University Press.

Sartre, J-P 1944, 1989 ed. No Exit and Other Plays. New York: Vintage. 
How to cite this article: Chiujdea, M 2013 Maurice Merleau-Ponty on Violence and Marxism. Opticon1826, 15: 7, pp.1-15, DOl: http://dx.doi.org/10.5334/opt.be

Published: 4 July 2013

Copyright: (c) 2013 The Author(s). This is an open-access article distributed under the terms of the Creative Commons Attribution 3.0 Unported License (CC-BY 3.0), which permits unrestricted use, distribution, and reproduction in any medium, provided the original author and source are credited. See http://creativecommons.org/licenses/by/3.0/.

] $\mathbf{u}\left[\begin{array}{l}\text { Opticon1826 is a peer-reviewed open access journal published by } \\ \text { Ubiquity Press }\end{array}\right.$ 